Please cite this paper as follows: Verleye, Katrien, Paul Gemmel and Deva Rangarajan (2014), "Managing Engagement Behaviors in a Network of Customers and Stakeholders: Evidence From the Nursing Home Sector," Journal of Service Research, 17 (1), 68-84.

\title{
Managing Engagement Behaviors in a Network of Customers and Stakeholders:
}

Evidence from the Nursing Home Sector

\section{Katrien Verleye}

PhD Candidate, Center for Service Intelligence - Department Management, Innovation, and Entrepreneurship at Ghent University (Tweekerkenstraat 2, Ghent 9000, Belgium), phone: (0032) 9 26434 94, cell phone: (0032) 4988417 46, e-mail: katrien.verleye@ugent.be.

\section{Paul Gemmel}

Associate Professor, Center for Service Intelligence - Department Management, Innovation, and Entrepreneurship at Ghent University (Tweekerkenstraat 2, Ghent 9000, Belgium), phone: (0032) 9 26435 18, e-mail: paul.gemmel@ugent.be.

\section{Deva Rangarajan}

Associate Professor, Department Marketing at Vlerick Business School (Reep 2, Ghent 9000, Belgium), phone: (0032) 921092 03, e-mail: deva.rangarajan@vlerick.com.

\section{Acknowledgment}

The authors would like to thank Bart Larivière, Patrick Van Kenhove, Valarie Zeithaml, the editor, and three anonymous reviewers for their comments on earlier drafts of this paper. 


\section{ABSTRACT}

Firms striving for long-term profitability need to build stronger customer-firm relationships by getting their customers more engaged with the firm. One path to this end is introducing practices to manage different forms of customer engagement behaviors (CEBs). To develop more effective and efficient CEB management practices, this research proposes and empirically tests a theoretical model on managerial and psychological processes to encourage CEBs that are embedded in a broader network of customers and stakeholders. Based on qualitative and quantitative studies in nursing homes, we demonstrate that organizational support and overall service quality towards significant others influence some forms of CEBs - more particularly feedback and positive word-of-mouth behaviors - through customer affect towards the organization. It is interesting to note that customer affect towards the organization encourages word-of-mouth behaviors, while it discourages feedback behaviors. Conversely, managerial processes that increase customer role readiness - such as organizational socialization and support from other customers - were found to have a positive impact on all forms of CEBs. This research helps managers of nursing homes and other services with a broad network of customers and stakeholders to improve existing CEB management practices and develop new CEB management practices that are beneficial for the firm and its stakeholders. 
To generate long-term profitability, researchers and practitioners increasingly recognize the importance of building stronger customer-firm relationships by engaging customers with the firm (Kumar et al. 2010). Examples of practices to engage customers include: referral rewards (e.g., Bank of America paying customers for referrals), new product and service development platforms (e.g., "My Starbucks Idea" where customers can post new product and service ideas), and customer communities (e.g., Weight Watchers meetings where people give and get advice on losing weight). All these examples illustrate practices to manage customer engagement behaviors (CEBs).

In line with van Doorn et al. (2010), we define CEBs as behavioral manifestations of customer engagement towards a firm, after and beyond purchase. CEBs can contribute to the firm's performance in two ways: (1) CEBs in interactions with firms and its employees - such as customers giving suggestions for service improvement - result in cost advantages for firms while ensuring rewarding customer experiences (Hoyer et al. 2010), and (2) CEBs in interactions with other customers - such as customers spreading word-of-mouth or writing online reviews - affect other customers' attitudes and behaviors towards firms (Gupta and Harris 2010).

Given the potential impact of CEBs on the firm's performance, firms are increasingly introducing practices to manage CEBs (Verhoef, Reinartz, and Krafft 2010). To improve the effectiveness and efficiency of these practices, further inquiry into CEB management practices is needed (Brodie et al. 2011). Our research provides insights into how these practices encourage CEBs and generates a better understanding of processes that underlie successful CEB management practices.

This research focuses on firm-related processes that underlie successful CEB management practices, which are labeled as managerial processes and include organizational socialization (i.e., the degree to which customers get behavioral guidelines from the organization), organizational support (i.e., the degree to which customers get practical or emotional help from the organization), and support from other customers (i.e., the degree to which customers get practical or emotional help from other customers). Additionally, this research also looks into customer-related processes that underlie successful CEB management practices, more particularly customer role readiness (i.e., the 
degree to which customers feel prepared for encounters with the organization) and customer affect (i.e., the degree to which customers have positive feelings about the organization). These processes are labeled as psychological processes.

Our main research objective is to empirically test a theoretical model on managerial and psychological processes to encourage CEBs that are embedded in a broader network of customers and/or other stakeholders. In other words, this research centers on CEBs that have a focus on not only the firm, but also other customers and/or stakeholders. Examples include parents who engage in school activities to show their engagement towards not only the school and its teachers but also their child (Hoover-Dempsey and Sandler 1997), people who participate in volunteer work to express their engagement towards both the volunteering organization and less fortunate others (Mowen and Sujan 2005), and sport fans who attend sporting events to show their engagement towards both the sports team and the fan community (Pons, Mourali, and Nyeck 2006).

Responding to a call for CEB research in health care (van Doorn et al. 2010), our research investigates CEBs embedded in a broader network of customers and/or stakeholders in nursing homes, which are institutions for people who need nursing, personal, psychological and paramedical care and assistance with mobility and daily living activities 24 hours a day (here, elderly people with mental and/or physical disabilities). In this setting, our research focuses on family members of nursing home residents, since their CEBs can express their engagement towards the nursing home and its employees along with the actual nursing home residents.

By looking at different forms of CEBs, this research builds on previous CEB research that addressed CEBs on a piecemeal basis (van Doorn et al. 2010). An integrative approach of CEBs also helps to identify overlapping antecedents and therefore improves our understanding of CEBs. More importantly, this research further improves our CEB understanding by providing empirical evidence for (1) the occurrence of CEBs embedded in a broader network of customers and/or stakeholders - a phenomenon that is not limited to nursing home or health care services - and (2) managerial and psychological processes to encourage these CEBs. 
From a managerial viewpoint, this research can help managers of nursing homes and other services with a broad network of customers and/or stakeholders to improve existing CEB management practices and even develop new practices. By carefully managing CEBs that occur within the broader network of customers and/or stakeholders related to consumers, nursing homes and other high-contact services even have the potential to better meet consumers' needs while also reducing the workload for their frontline employees. Since frontline employees often feel stressed due to consumers with variable, complex, and distinctive needs and a high workload (Singh 2000), our research also contributes to people's well-being.

In the next section, we discuss different forms of CEBs and a theoretical model on managerial and psychological processes to encourage CEBs embedded in a broader network of customers and/or stakeholders. We then describe the results of three studies in nursing homes. Finally, we discuss the theoretical and practical implications, the limitations, and future research directions.

\section{CEBS IN A BROADER NETWORK OF CUSTOMERS AND STAKEHOLDERS}

As mentioned above, customer engagement behaviors (CEBs) are customers' behavioral manifestations towards a firm, after and beyond purchase. Although these behavioral manifestations have also been labeled as 'customer engagement' (e.g., Kumar et al. 2010), we reserve 'customer engagement' to refer to the psychological state reflecting customers' interactive, co-creative experiences with a firm - as also suggested by Brodie et al. (2011). Brodie et al. (2011) argue that customer engagement as a psychological state can have cognitive, emotional, and behavioral dimensions. Following this reasoning, CEBs refer to voluntary, discretionary customer behaviors with a firm focus. The firm focus differentiates CEBs from more traditional relational concepts as customer participation and involvement (Brodie et al. 2011). Based on a literature review, we identified five forms of CEBs that benefit the firm and its stakeholders. In this section, (1) we discuss these CEBs based on the context in which they occur, and (2) we evaluate the degree to which these CEBs are 
observed in the literature on family members of nursing home residents (hereafter, family members).

\section{CEBs in Interactions with the Firm and its Employees}

Customers have several opportunities to show their engagement to the firm and its employees, since they increasingly participate in the creation, production, and delivery of service (Zeithaml, Bitner, and Gremler 2009). Customers usually exhibit three types of CEBs in interactions with firms and their employees: cooperation, feedback, and compliance.

Cooperation. As a result of their participation in service processes, customers can show benevolent acts to facilitate service exchanges (Bove et al. 2009) and help employees (van Doorn et al. 2010). We label benevolent acts to help employees to do their work as cooperation. This form of CEB is very common among family members. A couple of studies indicate that family members can cooperate with frontline employees by providing information (e.g., medical history about the resident) and assistance (e.g., helping with meals, taking their relatives for walks...). By doing so, family members aim to contribute to the resident's well-being and in the meanwhile reduce the workload for nursing home employees (Gaugler 2005; Ross, Rosenthal, and Dawson 1997). As a result, different forms of cooperation between family members and frontline employees can be seen as engagement behaviors towards the nursing home resident as well as the nursing home and its employees.

Feedback. Another way to show engagement to the firm and its employees is by giving feedback. Customers can give feedback to the firm and its employees via suggestions for service improvements (Bettencourt 1997; Bove et al. 2009) or through participation in new product and service development processes (Kumar et al. 2010). The family member literature confirms that some family members do not only monitor the quality of care but also give guidelines to frontline employees about how to care for residents. These behaviors help family members to influence frontline employees to deliver higher quality of care for the resident (Gaugler 2005) and achieve a harmonious 
relationship with employees (Lau et al. 2008). As a result, feedback behaviors can be considered as behavioral manifestations of customer engagement towards both nursing home residents and the nursing home and its employees.

Compliance. In general, the success of customer participation in service processes also depends on the degree to which customers comply with organizational rules and procedures (Bolton and Saxena-lyer 2009). The degree to which customers comply with organizational rules and procedures is labeled as compliance. In line with van Doorn et al. (2010), we consider compliance as a form of CEB. The reason is that even though everyone is expected to obey organizational regulations, many people simply do not (Podsakoff et al. 2000). This also holds for family members. According to Bauer (2006), for instance, clear expectations exist about how family members should conduct themselves, but not all family members behave well. Examples of unacceptable behaviors are not showing respect for the nursing home staff and ignoring nursing home requests. Given that not all family members comply with the organization's rules and procedures, we consider family member compliance as a behavioral manifestation of their engagement towards the nursing home and its employees. Additionally, family members can comply to ensure good quality of care for the nursing home resident (Gaugler 2005).

\section{CEBs in Customer-to-Customer Interactions}

In an increasingly networked society, customers cannot only show CEBs in interactions with firms and their employees. Customers can also show CEBs in customer-to-customer (C2C) interactions by helping other customers and spreading positive word-of-mouth behaviors.

Helping other customers. The CEB literature holds that customers can help one another by expressing empathy (Rosenbaum and Massiah 2007), encouraging each other to show appropriate behaviors (Bove et al. 2009), or helping each other to get better service experiences (Kumar et al. 2010). The family member literature reveals that family members do not only help their own relative, but also support new nursing home residents and their family members (Peak 2000). As a result, 
helping other customers - more particularly other nursing home residents and their relatives - can be seen as a behavioral manifestation of customer engagement towards the firm and its employees.

Positive word-of-mouth. According to the CEB literature, customers can show their engagement towards a firm by spreading word-of-mouth (Rosenbaum and Massiah 2007), or recommending the firm to other customers (Groth 2005). These behaviors are labeled as positive word-of-mouth (WOM). Van Doorn et al. (2010) argue that positive WOM - and more particularly referrals - are even more important than repurchase behaviors for health care organizations. The family member literature, however, does not pay attention to these CEBs. Mintz (1994) is an exception to the rule when arguing that "family members can be your most ardent supporters - or your most cutting critics" (p. 22). As a result, these forms of CEBs towards the nursing home deserve particular attention.

In sum, both customers in general and family members can show five forms of CEBs. A specific characteristic of family members is that they show CEBs to express their engagement towards the nursing home and its stakeholders and contribute to their relative's well-being. This phenomenon where customer engagement extends beyond dyadic interactive experiences - is also discussed by Brodie et al. (2011), who argue that specific customer-firm interactions may also occur within broader networks of customers and/or stakeholders. In other words, the embeddedness of CEBs in a broader network of customers and/or stakeholders is - as mentioned earlier - not limited to nursing homes.

\section{THEORETICAL FRAMEWORK AND HYPOTHESES}

In this section, we provide a theoretical framework and hypotheses about the relationships among managerial processes, psychological processes, and different forms of CEBs that are embedded in a broader network of customers and/or stakeholders. Figure 1 summarizes the hypothesized relationships. 
Insert Figure 1 about here

Drawing from resource exchange theory and affect theory of social exchange, we argue that managerial processes that generate positive customer affect towards the firm result in CEBs that benefit the firm and its stakeholders. Resource exchange theory (Foa 1971) holds that people exchange resources that are similar in terms of concreteness and particularism. Based on concreteness and particularism, six types of resources are derived, namely goods, services, status, information, money, and love. Drawing from resource exchange theory, we consider CEBs as forms of 'love' towards a firm, which result from a firm's investment in the customer beyond mere economic obligations (Bettencourt 1997). In line with social exchange theory (Blau 2004), we label exchanges beyond mere economic obligations as 'social exchanges'. The affect theory of social exchange (Lawler 2006) holds that social exchanges are driven by customer affect. Based on this theory, we hypothesize that higher levels of customer affect towards the firm (i.e., positive feelings towards the firm) increase customers' likelihood to show CEBs that benefit the firm and its stakeholders. The key question then revolves around which managerial processes generate customer affect towards the firm among customers embedded in a broader network of other customers and stakeholders.

We suggest that customer affect is generated by organizational support. Bettencourt (1997) defined organizational support as the degree to which customers get practical or emotional help from the organization beyond minimally required levels of customer service. Organizations providing technical assistance to optimize customers' experience and frontline employees showing empathy towards the customer - all of these examples illustrate organizational support. Previous research suggests that organizational support generates a better customer-firm relationship and improves customer satisfaction with the firm (Claycomb and Martin 2002). Since customer satisfaction with a firm reflects customer affect towards the firm, we hypothesize that higher levels of organizational support augment customer affect towards the firm. 
The same argument goes for overall service quality. Previous research suggests that better overall service quality can increase customers' satisfaction with the firm, and consequently their affect towards the firm (Cronin and Taylor 1992). Based on the family member literature, we argue that their affect towards the nursing home also depends on service quality. On the one hand, there is some evidence that the quality of the interactions between family members and frontline employees - and more particularly the degree to which frontline employees share information about the resident's treatment with family members - drives family members' affect towards the organization (Duncan and Morgan 1994). On the other hand, previous research has shown that family members' affect towards the nursing home largely depends on the quality of care for the nursing home resident (Haesler, Bauer, and Nay 2007). Based on this evidence, we argue that the degree to which nursing home residents' well-being is taken into account - and thus the overall service quality towards the nursing home resident - influences family members' affect towards the organization. In other words, family members' affect towards the organization depends on the overall service quality towards significant others (here, nursing home residents). The importance of overall service quality towards significant others reflects the embeddedness of CEBs in a broader network of customer and stakeholders. In contexts where CEBs are embedded in a broader network of customers and stakeholders, we hypothesize that customers' affect towards the organization and consequently their likelihood to show CEBs depends on overall service quality towards significant others.

Hypothesis 1: (a) Organizational support and (b) overall service quality towards significant others generate higher levels of customer affect towards the firm among customers who are embedded in a broader network of customers and/or stakeholders.

Hypothesis 2: Higher levels of customer affect towards the firm result in higher levels of (a) compliance, (b) cooperation, (c) feedback, (d) helping other customers, and 
(e) positive WOM among customers who are embedded in a broader network of customers and/or stakeholders.

Drawing from role theory (Kahn et al. 1964), we assume that customers' willingness to show CEBs that benefit the firm and its stakeholders depends not only on customers' affect towards the firm but also on their role readiness. We define customer role readiness as the degree to which customers feel prepared for encounters with the organization in terms of feeling confident and having the appropriate knowledge and skills. Previous research merely demonstrated that customer role readiness affects their compliance with the organizational rules and procedures in various industries (Auh et al. 2007; Meuter et al. 2005). We propose that not only customer compliance but also other CEBs depend on customer role readiness. Customers who do not have the appropriate knowledge or skills for encounters with the organization might be less willing to cooperate with the frontline employees, give suggestions for service improvement, or help other customers within the organization. Moreover, the same goes for customers who do not feel confident for encounters with the organization. It is not inconceivable that a lack of confidence for encounters with the organization also reduces their willingness to spread positive WOM behaviors. The central question, however, is how firms can increase customer role readiness within the organization.

Several conceptual papers on customer role readiness have emphasized the importance of organizational socialization, which is a managerial process (1) pertaining to the development of customer skills, knowledge, and attitudes relevant to the marketplace in general and (2) preparing customers with organizationally specific behavioral guidelines (Hsieh and Yen 2005; Kelley, Skinner, and Donnelly 1992). In this paper, we define organizational socialization as the degree to which customers get specific behavioral guidelines from the organization. Previous research has shown that organizations can socialize their customers through communication of the expectations regarding their role (Mills and Morris 1986), and customer education (Lachman 2000; Lengnick-Hall 1996). Since these forms of organizational socialization can help customer to learn specific organizational values and develop the knowledge and skills needed to interact with frontline employees and other 
customers, we hypothesize that organizational socialization increases customer role readiness, resulting in higher levels of CEBs. Moreover, we argue that the same goes for organizational support, since organizational support can render customers more prepared for their encounters with the organization. Customers, however, cannot only get support from the organization, they can also get support from other customers (Rosenbaum and Massiah 2007). We argue that support from other customers has no impact on customers' affect towards the firm, but affects the degree to which customers feel prepared for encounters with the organization. Therefore, we hypothesize:

Hypothesis 3: (a) Organizational socialization, (b) organizational support, and (c) support from other customers generate higher levels of customer role readiness among customers who are embedded in a broader network of customers and/or stakeholders.

Hypothesis 4: Higher levels of customer role readiness result in higher levels of (a) compliance, (b) cooperation, (c) feedback, (d) helping other customers, and (e) positive WOM among customers who are embedded in a broader network of customers and/or stakeholders.

\section{EMPIRICAL STUDIES}

As background to the main study that tests our hypotheses among family members, we conducted two exploratory studies. Given the importance of organizational socialization, organizational support, and support from other customers to deal with CEBs, the first exploratory study explored how family members are socialized and supported within nursing homes. The goal was to identify key characteristics of socialization and support in nursing homes to develop sound measures for the main study. To gain more insight into the exact nature and measurement of different CEBs, the second exploratory study investigated how and to which degree family members 
show CEBs that are embedded in a broader network of customers and/or stakeholders. Based on the findings of the two exploratory studies, we designed the main study.

\section{EXPLORATORY STUDY 1}

\section{Research Design}

To explore how nursing homes socialize and support family members of their residents, we opted for a case study design. This design is appropriate to investigate exploratory "how" and "why" questions about a contemporary set of events over which the investigator has little or no control (Yin 2009). To fully capture the key characteristics of socialization and support in nursing homes, we explored socialization and support of family members of new residents throughout the admission process (i.e., from the first contact of family members with the nursing home until one month after their relative's admission in the nursing home). We investigated socialization and support of family members throughout the admission process in two Belgian nursing homes, thereby increasing the study's external validity (Eisenhardt and Graebner 2007). More particularly, we followed a sampling strategy that allowed for literal replication, which means that cases were selected to provide similar results (Yin 2009). To bring about literal replication, we identified two nursing homes for elderly people with a strong customer focus via discussions with nursing home experts and an exploratory interview with the nursing home manager.

To make the conclusions more accurate, we gathered multiple sources of evidence. First, we observed family member socialization and support throughout the admission process. To reduce the risk that events proceed differently because these are being observed, only one researcher was involved in the observations. This researcher observed every interaction between the new resident's family members and the nursing home ( $n=11$ interactions in nursing home 1 and $n=15$ interactions in nursing home 2), so that they got used to the researcher's presence. Second, we gathered documentation, archival records, and physical artifacts related to organizational socialization and support throughout the admission process, which include the nursing home website, information 
brochures, admission forms, team meeting reports, nursing home residents' files, and posters within the nursing home. Finally, we conducted focused interviews with all actors involved in the socialization and support of family members, including residents, family members, nursing personnel, social assistant, administrative staff, and managers. Key questions were "how are family members of new residents prepared for admission" and "which forms of support do family members get within this nursing home". In total, we interviewed 12 people in nursing home 1 and 13 people in nursing home 2 .

By having different sources of evidence, there is convergence of evidence and real data triangulation, which increases the construct validity. Construct validity was also improved by asking key informants to review draft case study reports (Yin 2009). The case study data were managed and analyzed using Nvivo8. Following the open coding procedure of Strauss and Corbin (1998), we searched for patterns within cases. In each case, we identified (1) different socialization and support tactics, and (2) differences in the occurrence of socialization and support tactics across stages of the admission process. A cross-case synthesis was conducted to compare the patterns in both cases (Yin 2009). Two investigators analyzed the data to increase the study's internal validity and reliability.

\section{Findings}

In the admission process in the two nursing homes, we identified five stages. In stage I, family members register their relative on the nursing home's waiting list. In stage II, the nursing home invites registered customers - whose care profile matches an available room - for admission. If registered customers are open to admission, the admission of the new resident is prepared in stage III. In stage IV, the new resident enters the nursing home. In stage $\mathrm{V}$, new residents and their relatives get used to the new environment. In each stage, different organizational socialization and support tactics were identified (see summary in Table 1). 
Insert Table 1 about here

Table 1 shows that nursing homes mainly socialize family members via oral information and guidelines (see Example 1), although this overlaps with the written information and guidelines (e.g., websites, and forms). A key finding is that almost all frontline employees are involved in providing guidelines and information. Moreover, the information provided by frontline employees in stage I, II, and III is twofold. On the one hand, frontline employees focus on promoting the organization by centering on strengths and benefits (see Example 2). On the other hand, frontline employees focus on setting the right expectations (see Example 3). Further inquiry showed that this results from the experience that too low expectations make customers choose for another organization in stage II, while too high expectations generate disappointed customers in all subsequent stages. The effectiveness of the frontline employee communication depends thus on the consistency between the provided information and the nursing home reality.

Example 1: "The social assistant told us that we are allowed to decorate the room, so we'll pack some of the paintings" (family member to interviewer)

Example 2: "We also mention price and bonuses, since that can sometimes persuade people" (frontline employee to interviewer)

Example 3: "We will try to make your family member feel comfortable, but it is not like home" (frontline employee to family member)

Table 1 shows that family members also get different forms of support throughout the admission process. A key finding is that different forms of support are mainly provided by frontline employees. Frontline employees support family members by (1) trying to understand their needs, (2) being open to their questions and concerns and showing empathy for their situation (see Example 4), and (3) offering practical help (see Example 5). 
Example 4. "The employees are very friendly and they always say 'please do not hesitate to contact us if you have any question'"' (family member to interviewer)

Example 5. "I have called the technical department to find out whether a satellite dish can be installed to receive the equestrian TV channel in his room (...) it would be nice if we could arrange this for you " (frontline employee to family member)

After the nursing home admission (stage $\mathrm{V}$ ), family members can also get support from other family members and residents. Support from other customers includes practical help (e.g., information about the nursing home procedures) and emotional support (e.g., sharing experiences with Dementia in discussion groups).

\section{Conclusion}

This study showed that family members support each other by providing (1) practical help and (2) emotional support. A key finding, however, was that frontline employees were crucial for socialization and support. Frontline employees socialized family members through (1) guidelines about family members' role, and (2) communication that is in line with the nursing home reality, while they supported family members by (1) trying to understand their needs, (2) providing emotional support, and (3) offering practical help. These key characteristics are used to select sound measures for organizational socialization, organizational support, and support from other customers in the main study.

\section{EXPLORATORY STUDY 2}

\section{Research Design and Sample}

To better understand the exact nature and measurement of family members' CEBs, the second exploratory study investigates how and to what degree family members show CEBs. We gathered these CEB data from the family member and frontline employee perspective. By incorporating these two perspectives, we clarify whether family members and frontline employees identify similar forms 
and levels of CEBs in nursing homes. In two Belgian nursing homes, we distributed self-administered questionnaires to family members and frontline employees. Of the 200 family members that received a questionnaire, 160 usable questionnaires were returned ( $80 \%$ response rate). The respondent group was $64 \%$ women and mainly included partners and children of residents. Since the majority of family members in nursing homes are adult daughters and wives (Dupuis and Norris 1997), this sample is representative. Of the 200 frontline employees that received a questionnaire, 141 usable questionnaires were returned (71\% response rate). The respondent group was $95 \%$ women and mainly included nursing personnel, which is in line with nursing home staff composition.

\section{Measures}

The CEB measures in the family member and frontline employee questionnaires were adaptations from the same measures. Whereas frontline employees were asked to rate CEBs of all family members within the nursing home, family members were asked to only rate their individual CEBs within the nursing home. After evaluating the face and content validity of the CEB measures through interviews with five family members and five frontline employees, we finalized the family member and frontline employee questionnaire (see Table 2). Both versions include measures for five forms of CEBs. Compliance was measured by four items from Groth (2005). Two items to capture cooperation were adapted from Bettencourt (1997). Three items for helping other customers were taken from Groth (2005). Feedback was captured by adapting four items from Bettencourt (1997) and Groth (2005). Finally, three items to measure positive WOM were adapted from Bettencourt (1997) and Groth (2005). All items used a 5-point scale, ranging from strongly disagree (1) to strongly agree (5).

As recommended by Netemeyer, Bearden, and Sharma (2003), we conducted an exploratory factor analysis and an initial item and reliability analysis for the family member and frontline employee sample to identify items with cross-loadings and items that were poorly correlated with the remaining items in each scale. Based on these analyses, we deleted one item of the feedback scale in both samples ("I/Family members always fill out customer satisfaction surveys"). A final 
principal axis factoring (oblique rotation) extracted five factors with eigenvalues greater than one, which corresponded with the five CEBs identified in the literature review. Finally, we assessed the five-factor structure using confirmatory factor analysis (CFA; LISREL 8.50).

\section{Analyses and Findings}

The measurement model for both samples performed well. Firstly, the ratios of chi-square to degrees of freedom, $\chi^{2}(139.91) / d f(80)=1.75$ for the family member sample and $\chi^{2}(116.28) / d f(80)=1.45$ for the frontline employee sample, were between 1 and 2 . Secondly, the comparative fit index (CFI), 0.98 for the family member sample and 0.94 for the frontline employee sample, and Tucker-Lewis index (TLI), 0.97 for the family member sample and 0.93 for the frontline employee sample, were all above common benchmarks of 0.90 . Finally, the root mean square error of approximation (RMSEA) was 0.07 for both samples, which represents an acceptable fit (Byrne 1998; Netemeyer, Bearden, and Sharma 2003).

Insert Table 2 about here

Table 2 shows individual items and item loadings for the two samples. Both samples showed convergent validity, because all item loadings were significant, almost all construct reliabilities (CR) were greater than 0.70 , and almost all average variances extracted (AVE) exceeded 0.50 (see Table 3). Table 3 also provides evidence for discriminant validity in both samples, since the square root of the AVE for almost all constructs exceeded the factor correlations (Fornell and Larcker 1981). Only the feedback construct in the frontline employee questionnaire failed to meet the standards for convergent and discriminant validity $(C R=0.65 ; A V E=0.40)$. Further analysis revealed that this problem could be solved by deleting one item ("Family members let the nursing home personnel know when they give good service"). After deleting this item, the convergent and divergent validity standards were met $(C R=0.70 ; A V E=0.54)$. Additionally, the adjusted model had a better overall fit 
$\left(\chi^{2}(90.67) / d f(67)=1.35 ; \mathrm{CFI}=0.96 ; \mathrm{TLI}=0.94 ; \mathrm{RMSEA}=0.05\right)$. A closer examination revealed that this problematic item reflected customers' willingness to communicate their service experience rather than their willingness to give service improvement suggestions. Although only frontline employees seemed to distinguish between these forms of feedback, we also deleted the corresponding item in the family member questionnaire to be able to compare feedback behavior from the family member and frontline employee perspective.

Insert Table 3 about here

Since we found similar factor structures and patterns of salient and non-salient loadings across samples, we conclude that family members and frontline employees identified similar forms of CEBs. Regarding the degree to which family members show different forms of CEBs in the two nursing homes, there was also congruence between the family member and frontline employee perspective. In both nursing homes, family members and frontline employees reported the lowest means for cooperation and helping other customers, while higher means were reported for feedback and positive WOM. Further analyses confirmed that there were no significant differences between the family member and the frontline employee perspective on cooperation, helping other customers, feedback behavior and positive WOM in the two nursing homes. In the two nursing homes, however, we observed a significant difference between family members and frontline employees regarding compliance. Family members rated themselves significantly higher for compliance than frontline employees, $F(1,179)=52.53 ; t=7.25 ; p=0.00$ in nursing home 1 and $F(1,118)=72.91 ; t=8.54 ; p=0.00$ in nursing home 2. Additionally, compliance was perceived as one of the most common forms of CEBs among family members in both nursing homes, while it is one of the least common CEBs from the frontline employee perspective in both nursing homes. Finally, there were also differences across the two nursing homes. Compared to family members in nursing home 1 , family members in nursing home 2 reported significantly more compliance, $F(1,158)=14.31 ; t=3.78 ; p=0.00$, cooperation, 
$F(1,158)=7.50 ; t=2.74 ; p=0.01$, helping other customer behavior, $F(1,158)=10.12 ; t=3.18 ; p=0.00$, and positive WOM, $F(1,158)=27.76 ; t=5.27 ; p=0.00$. Similar differences between CEBs in nursing home 1 and 2 were reported by frontline employees, although only the difference in positive WOM was significant, $F(1,139)=9.86 ; t=3.14 ; p=0.00$.

\section{Conclusion}

This study demonstrated that self-reported measures can be used to measure CEBs, since (1) family members and frontline employees identified similar forms of CEBs and (2) there is also congruence regarding the degree to which family members exhibit different forms of CEBs from the family member and frontline employee perspective. The only exception is compliance, which might be due to different interpretations of compliance between family members and frontline employees. Another explanation is that the family member sample only included family members willing to participate in the survey and therefore also more obedient family members, whereas frontline employees evaluated the CEBs of all family members within the organization. Regardless of the explanation, this finding implies that self-reported measures for compliance can overestimate the occurrence of this form of CEB within the organization. The feedback scale can be improved by replacing the problematic item ("I let the nursing home personnel know when they give good service") by items that better reflect customers' willingness to give suggestions for service improvement ("I make constructive suggestions to this organization to improve its service" and "I give useful ideas to someone in the nursing home"). Finally, further investigation of how to manage CEBs is desirable, since there are differences in CEB levels across organizations.

\section{MAIN EMPIRICAL STUDY}

\section{Research Design, Measures, and Sample}

The main empirical study aimed to test our hypotheses regarding managerial processes to encourage CEBs that are embedded in a broader network of customers and stakeholders and the 
associated psychological processes. We tested our hypotheses using data from self-administered questionnaires among family members of nursing home residents, which built on the findings of the two exploratory studies.

Exploratory study 1 identified key characteristics of organizational socialization and support in nursing homes. As prior research has conceptualized that organizations can socialize customers through communication and education, in the context of this study we captured organizational socialization by three items from the communication effectiveness scale of Sharma and Patterson (1999) and three items from the training scale of Taormina (2004). Some of these items were reformulated to better reflect the finding that frontline employees play a crucial role in communication and training of family members of nursing home residents. Measures for organizational support and support from other customers were based on respectively a four-item and a three-item scale of Yi and Gong (2008), because these scales reflected the key characteristics of organizational support and support from other customers that were identified in exploratory study 1. Table 4 gives an overview of the other measures.

Furthermore, we also included measures for family members' motives to show different forms of CEBs, which were adapted from Chan, Yim and Lam (2010). Three items referred to motives related to the nursing home resident, more particularly family members' desire to contribute to residents' well-being ("In this nursing home, I behave as I do because (1) this increases the quality of the service for the nursing home resident, (2) this gives more control over the service quality for the nursing home resident, and (3) this generates more customized services for the nursing home resident"). Two items referred to motives related to the nursing home, more particularly family members' desire to connect with nursing homes and their employees ("In this nursing home, I behave as I do because (1) this helps me to build better relationships with the service provider and (2) this makes the service interaction more enjoyable"). Cronbach's alphas for these scales are respectively 0.93 and 0.89 .

Since the findings of exploratory study 2 suggest that CEB management differs across nursing homes, we gathered data in different nursing homes. Based on convenience sampling, thirteen 
Belgian nursing homes were selected, which together house 1,430 residents. To generate a representative sample of residents' family members, nursing home managers informed family members through different channels (e.g., newsletter, posters, and e-mails). In their communication to family members, they emphasized that study participation was voluntary and anonymous and external researchers analyzed the data.

A total of 2,000 questionnaires were delivered to the nursing homes, which were either mailed or delivered to family members. This resulted in 413 usable questionnaires ( $21 \%$ response rate). The sample was $62 \%$ women and children were again the most frequent respondents (65\%), thereby representing the population.

\section{Analyses and Findings}

Common method variance. Since data on managerial processes, psychological processes, and forms of CEBs come from family members, there is potential for common method variance. As recommended by Podsakoff et al. (2003), we reduced the potential for common method bias by using measures based on existing scales or carefully constructing items, proximally separating measures of predictors and criterion variables, and protecting the respondents' anonymity by allowing them to deposit the anonymous questionnaires in a closed drop box at the entrance of the organization. Additionally, a Harmon's single-factor test was conducted, which showed that none of the factors accounted for the majority of covariances among items. Therefore, common method bias was not a serious threat to our analyses (Podsakoff et al. 2003).

Measure validation. A CFA was conducted to evaluate the fit of the measurement model. As shown in Table 4, the goodness-of-fit statistics showed a good fit. Additionally, the data also showed convergent and discriminant validity (see Table 5).

Insert Table 4 and Table 5 about here 
The nature of CEBs. As recommended by Raudenbusch and Bryk (2002), we ran unconditional hierarchical models for each CEB to get estimates of the amount of variance at the individual and nursing home level. Based on these estimates, we calculated the intra-class correlations (ICCs), which reflect the proportion of variance between nursing homes. Since all ICCs were below .10, we conclude that the proportion of variance between nursing homes was rather small. Therefore, we used an aggregated data set for further analyses. Hierarchical regression analyses were used to gain more insight into family members' motives to show CEBs, thereby controlling for gender, retirement, kinship with nursing home resident, and length of relationship with nursing home. Table 6 shows that the control variables added in step 1 explained a very low proportion of the variation in CEBs, while the addition of family members' motives to show CEBs in step 2 accounted for a significant $R^{2}$ increase. The results suggest that CEBs in interactions with other customers (helping other customers and positive WOM) are behavioral manifestations of customer engagement towards the nursing home and its employees, while CEBs in interactions with the nursing homes and its employees (compliance, cooperation, and feedback) express both their engagement to the nursing home and its employees and their desire to contribute to the nursing home resident's well-being.

Insert Table 6 and 7 about here

Model and hypothesis testing. The structural model was tested per form of CEB. Table 7 shows that the model fits were good. Moreover, the results largely supported our hypotheses, since almost all paths were significant and in the hypothesized direction (see Table 7). The only exceptions were the paths from customer affect to different forms of CEBs. Contrary to Hypotheses $2 a, 2 b$, and $2 d$, the paths from customer affect to compliance, cooperation, and helping other customers were nonsignificant. Additionally, we also rejected Hypothesis 2c, because the path from customer affect to feedback behavior was negative instead of positive. 
Alternative models. Since the proposed model represents one of several possible relationships among the constructs, we considered three alternative models. These models considered respectively (1) managerial processes, (2) psychological processes, and (3) managerial and psychological processes as direct predictors of CEBs. The results showed that few differences were observed regarding the incremental and comparative fit indices (i.e., CFI and TLI). Compared to the independent or null model, all models indicated a good fit. Based on the RMSEA and fit indices correcting for parsimony (i.e., parsimony goodness of fit index and parsimony normed fit index), however, the original model appeared to be the best representation of the data ${ }^{1}$.

\section{Conclusion}

The main empirical study demonstrated that family members' CEBs are embedded in a broader network of customers and stakeholders (such as the nursing home resident). Regarding managerial and psychological processes that encourage CEBs, the results showed that overall service quality towards significant others and organizational support influence feedback and positive WOM behaviors through customer affect towards the organization. It is remarkable that positive WOM behaviors are increased, while feedback behaviors are decreased. This finding implies that customers' willingness to give suggestions for service improvement is driven by a negative rather than a positive affect towards the nursing home. Surprisingly, overall service quality towards significant others and organizational support do not affect other forms of CEB through customer affect. More important was the effect of customer role readiness, which had a positive impact on all CEBs. Given their positive impact on customer role readiness, we consider organizational socialization, organizational support, and support from other customers as effective managerial processes to encourage CEBs. Finally, firms might also benefit from strategies centering on service quality towards significant others, since this affects positive WOM behaviors through increased customer affect.

\footnotetext{
${ }^{1}$ Further details about the alternative model results are available from the first author upon request.
} 


\section{GENERAL DISCUSSION}

\section{Theoretical Implications}

Our main research purpose was to test a model that would provide more insight into managerial processes to encourage CEBs. More particularly, we investigated which managerial processes encourage CEBs of nursing home residents' family members. By doing so, our research is the first to explicitly look at CEBs that are embedded in a broader network of customers and/or stakeholders. We show that customers who do not consume nursing home services - and thus customers who are not the direct service recipients - can show different forms of CEBs. By looking at these CEBs, this research extends the CEB management literature.

Our research also contributes to the CEB management literature by looking at different forms of CEBs (van Doorn et al. 2010). Contrary to prior CEB research, our integrated approach helps to identify managerial processes that contribute to different forms of CEBs and thus overlapping antecedents of CEBs. As a result, this research improves our understanding of CEBs and how these CEBs can be managed in an effective and efficient way. Additionally, we also build on existing CEB research by incorporating a largely overlooked form of CEB, namely compliance. Since firms increasingly involve customers in service processes, compliance is crucial for the customer experience and subsequently the firm's performance (Bolton and Saxena-lyer 2009). Interestingly, this research demonstrates that managerial processes to encourage compliance overlap with managerial processes to encourage other CEBs.

Furthermore, this research contributes to the CEB literature by addressing psychological processes through which managerial processes influence CEBs. The focus on both managerial and psychological processes responds to Van Doorn et al. (2010)'s call for empirical research that integrates firm-based (i.e., managerial processes) and customer-based antecedents (i.e., psychological state). Further inquiry of the interplay between customer-based and firm-based antecedents revealed that managerial processes affect CEBs by influencing customers' psychological state. In other words, psychological processes mediate the impact of managerial processes on CEBs. 
In line with affect theory of social exchange, this research demonstrates that overall service quality towards significant others and organizational support generate customer affect towards the organization, which affects different forms of CEBs. Interestingly, we find that customer affect towards the firm decreases rather than increases, customers' willingness to give feedback. In other words, customers with positive affect towards the firm are less likely to give feedback to the firm. One explanation is that firms mainly encourage customers to communicate their problems with the firm as input for service improvement and/or new service development activities. Another explanation is that customers who experience problems are more likely to give feedback for new service development and service improvement activities, since this might directly benefit them or their significant others. A final explanation is that customers with positive affect towards the firm do not want to increase frontline employees' workload by giving them feedback. Future research, however, should further investigate this issue.

In line with role theory, this research demonstrates that organizational socialization, organizational support, and support from other customers increase customers' role readiness, resulting in higher levels of all forms of CEBs. Since CEBs are behavioral manifestations of customer engagement towards the firm, this finding suggests that the degree to which customers know how to deal with the employees and other customers within the organization increases their engagement towards firm. This finding builds on the work of Libai et al. (2010), who argue that making sure that customers are self-confident when participating in a service should be a strategic goal of service providers. Future research, however, could investigate whether other psychological processes - such as customers' consumption goals - also increase customers' engagement towards the firm.

\section{Implications for Practice}

Our research yields some key insight for practitioners. First, we demonstrate that not only customers who consume services can show CEBs. Equally important is the broader network of customers and/or stakeholders. 
Next, the CEB scale provides practitioners with a tool to assess customers' likelihood to show CEBs. Given the consistency of the CEB scale for customers and frontline employees, we suggest that firms can use both scales to assess CEBs. Although this scale was tested in nursing homes, we believe that this scale is useful in other settings to assess and then react on CEBs.

Furthermore, this research helps business practitioners to develop more effective and efficient CEB management practices by showing that strategies centering on service quality towards significant others, organizational socialization, organizational support, and support from other customers encourage CEBs embedded in a broader network of customers and/or stakeholders. The way in which firms can generate service quality towards significant others and socialize and support customers, however, might differ across contexts. We explored key characteristics of effective organizational socialization and support in nursing homes, where we showed that these processes largely depend on frontline employees. We believe that other high-contact services might also benefit from organizational socialization and support via frontline employees, but the optimal way to socialize and support customers may vary across contexts.

By focusing on both managerial and psychological processes, our framework helps practitioners to think about alternate ways to increase customer role readiness and affect towards the firm. Firms can, for instance, socialize customers through online videos that balance between promoting the organization and setting the right expectations. Furthermore, firms can support customers by providing customer forums or online chat systems to talk with a firm representative.

Finally, this research suggests that efficient and effective CEB management practices help business practitioners to engage not only their consumers but also the broader network of customers and stakeholders. As a result, this research also has implications for customer relationship management, which is a top priority for many firms (Verhoef, Reinartz, and Krafft 2010). Many firms recognize the importance of generating deeper and more meaningful customer-firm connections (Kumar et al. 2010). By discussing managerial processes that help firms to build strong customer-firm relationships, we bring firms a step closer to a more relational view. 


\section{Limitations and Future Research Directions}

This research only focused on CEBs that benefit the firm and its stakeholders. Customers, however, can also show engagement behaviors that have detrimental effects for firms and their stakeholders (Kumar et al. 2010). Future research should investigate whether managerial processes to encourage beneficial CEBs can also discourage CEBs with detrimental effects for firms and their stakeholders.

Next, our research has shown that managerial processes to deal with CEBs largely depend on frontline employees. This might be a context-specific finding, since we only focused on nursing homes and thus high-contact services. This finding, however, is in line with previous research showing that frontline employees play a crucial role in many settings (Payne and Webber 2006). Nevertheless, future research should investigate (1) whether frontline employees are equally important in settings where customers have less emotional ties to CEBs, and (2) how firms can involve frontline employees in customer socialization and support in low-contact services.

Additionally, future research should investigate whether all frontline employees are able to manage CEBs. On the one hand, frontline employees need to invest time and energy in customer socialization and support, which increases their workload (Hsieh, Yen, and Chin 2004). On the other hand, frontline employees need to understand customers to socialize and support them in an efficient and effective way (Homburg, Wieseke, and Bornemann 2009). Since not all frontline employees might be able to manage CEBs and since the importance of their role might vary across settings, future research should explore less time-consuming socialization and support tactics (e.g., online chat functions).

Future research could also investigate whether the timing of different managerial processes affects customers' willingness to show CEBs. The exploratory study on how nursing homes socialize and support family members throughout the admission process, for instance, showed that nursing homes socialize and support family members already before the admission of new residents (see

stage I to IV in Table 1). Future research might provide more insight into the optimal timing of 
socialization and support by using longitudinal panel data. These data might also improve our understanding of the evolution of CEBs over time (Brodie et al. 2011).

Furthermore, our research focused on managerial and psychological processes to deal with CEBs, but did not look into individual differences that affect customers' willingness to show CEBs. Previous research, however, suggests that the degree to which customers show CEBs might also depend on individual customer traits, such as self-enhancement needs (van Doorn et al. 2010). The main study findings support this suggestion, since CEB levels varied both across and within organizations. Therefore, future research should integrate individual customer traits as moderator for the impact of managerial processes on customers' likelihood to show CEBs.

Finally, our research looked at CEBs of customers who are not consuming services but related to service consumers. One might wonder whether our results also hold for customers who consume services. We argue that our results also apply to consuming customers if they are embedded in a broader network of customers and/or stakeholders. Consider, for instance, people who go on attractions in a theme park - and thus pay for these attractions - to accompany their children. Future research can improve our understanding of CEBs that are embedded in a broader network of customers and/or other stakeholders. One path to these ends is empirical research that includes the interplay between all actors involved in engagement processes over time. 


\section{REFERENCES}

Auh, Seigyoung, Simon J. Bell, Colin S. McLeod, and Eric Shih (2007), "Co-Production and Customer Loyalty in Financial Services," Journal of Retailing, 83, 359-370.

Bauer, Michael (2006), "Collaboration and Control: Nurses' Constructions of the Role of Family in Nursing Home Care," Journal of Advanced Nursing, 54 (April), 45-52.

Bettencourt, Lance A. (1997), "Customer Voluntary Performance: Customers as Partners in Service Delivery," Journal of Retailing, 73 (Fall), 383-406.

Blau, Peter M. (2004), Exchange \& Power in Social Life. New York: Wiley.

Bolton, Ruth and Shruti Saxena-lyer (2009), "Interactive Services: A Framework, Synthesis and Research Directions," Journal of Interactive Marketing, 23 (February), 91-104.

Bove, Liliana L., Simon J. Pervan, Sharon E. Beatty, and Edward Shiu (2009), "Service Worker Role in Encouraging Customer Organizational Citizenship Behaviors," Journal of Business Research, 62 (July), 698-705.

Brodie, Roderick J., Linda D. Hollebeek, Biljana Juric, and Ana Illic (2011), "Customer Engagement: Conceptual Domain, Fundamental Propositions, and Implications for Research," Journal of Service Research, 14 (August), 252-271.

Byrne, Barbara M. (1998), Structural Equation Modeling with Lisrel, Prelis, and Simplis: Basic Concepts, Applications, and Programming. New York: Psychology Press.

Chan, Kimmy W., Chi K. Yim, and Simon S. K. Lam (2010), "Is Customer Participation in Value Creation a Double-Edged Sword? Evidence from Professional Financial Services across Cultures," Journal of Marketing, 74 (May), 48-64.

Claycomb, Cindy and Charles L. Martin (2002), "Building Customer Relationships: An Inventory of Service Providers' Objectives and Practices," Journal of Services Marketing, 16, 615 - 635.

Cronin, Joseph J. and Steven A. Taylor (1992), "Measuring Service Quality - a Reexamination and Extension," Journal of Marketing, 56 (July), 55-68. 
Dagger, Tracey S., Jilian C. Sweeney, and Lester W. Johnson (2007), "A Hierarchical Model of Health Service Quality. Scale Development and Investigation of an Integrated Model," Journal of Service Research, 10 (November), 123-142.

Duncan, Marie T. and David L. Morgan (1994), "Sharing the Caring - Family Caregivers Views of Their Relationships with Nursing-Home Staff," Gerontologist, 34 (April), 235-244.

Dupuis, Sherry L. and Joan E. Norris (1997), "A Multidimensional and Contextual Framework for Understanding Diverse Family Members' Roles in Long-Term Care Facilities," Journal of Aging Studies, 11 (Winter), 297-325.

Eisenhardt, Kathleen M. and Melissa E. Graebner (2007), "Theory Building from Cases: Opportunities and Challenges," Academy of Management Journal, 50 (February), 25-32.

Foa, Uriel G. (1971), "Interpersonal and Economic Resources," Science, 171 (January), 345-351.

Fornell, Claes and David F. Larcker (1981), "Evaluating Structural Equation Models with Unobservable Variables and Measurement Error," Journal of Marketing Research, 18 (February), 39-50.

Gaugler, Joseph E. (2005), "Family Involvement, in Residential Long-Term Care: A Synthesis and Critical Review," Aging \& Mental Health, 9 (March), 105-118.

Groth, Markus (2005), "Customers as Good Soldiers: Examining Citizenship Behaviors in Internet Service Deliveries," Journal of Management, 31 (February), 7-27.

Gupta, Pranjal and Judy Harris (2010), "How E-Wom Recommendations Influence Product Consideration and Quality of Choice: A Motivation to Process Information Perspective," Journal of Business Research, 63 (September-October), 1041-1049.

Haesler, Emily, Michael Bauer, and Rhonda Nay (2007), "Staff-Family Relationships in the Care of Older People: A Report on a Systematic Review," Research in Nursing \& Health, 30 (August), 385398.

Homburg, Christian, Jan Wieseke, and Torsten Bornemann (2009), "Implementing the Marketing Concept at the Employee-Customer Interface: The Role of Customer Need Knowledge," Journal of Marketing, 73 (January), 64-81. 
Hoover-Dempsey, Kathleen V. and Howard M. Sandler (1997), "Why Do Parents Become Involved in Their Children's Education?," Review of Educational Research, 67 (Spring), 3-42.

Hoyer, Wayne D., Rajesh Chandy, Matilda Dorotic, Manfred Krafft, and Siddharth S. Singh (2010), "Consumer Cocreation in New Product Development," Journal of Service Research, 13 (August), 283-296.

Hsieh, An-Tien and Chang-Hua Yen (2005), "The Effect of Customer Participation on Service Providers' Job Stress," The Service Industries Journal, 25, 891-905.

Hsieh, An-Tien, Chang-Hua Yen, and Ko-Chien Chin (2004), "Participative Customers as Partial Employees and Service Provider Workload," International Journal of Service Industry Management, 15, 187-199.

Kahn, Robert L., Donald M. Wolfe, Robert P. Quinn, Diederick J. Snoek, and Robert A. Rosenthal (1964), Organizational Stress: Studies in Role Conflict and Ambiguity. New York: John Wiley and Sons.

Kelley, Scott W., Steven J. Skinner, and James H. Donnelly (1992), "Organizational Socialization of Service Customers," Journal of Business Research, 25 (November), 197-214.

Kumar, V., Lerzan Aksoy, Bas Donkers, Rajkumar Venkatesan, Thorsten Wiesel, and Sebastian Tillmanns (2010), "Undervalued or Overvalued Customers: Capturing Total Customer Engagement Value," Journal of Service Research, 13 (August), 297-310.

Lachman, Ran (2000), "Stepping into the Kitchen: Lay Clients as Co-Producers of a Professional Service," International Journal of Human Resource Management, 11 (June), 617-634.

Lau, Wai-Yin A., Yea-Ing L. Shyu, Li-Chan Lin, and Pei-Shan Yang (2008), "Institutionalized Elders with Dementia: Collaboration between Family Caregivers and Nursing Home Staff in Taiwan," Journal of Clinical Nursing, 17 (February), 482-490.

Lawler, Edward J. (2006), "The Affect Theory of Social Exchange," in Contemporary Social Psychology Theories, Peter J. Burke, ed. Stanford: Stanford University Press, 244-267. 
Lengnick-Hall, Cynthia A. (1996), "Customer Contribution to Quality: A Different View of the Customer-Oriented Firm," Academy of Management Review, 21 (July), 791-824.

Libai, Barak, Ruth Bolton, Marnix S. Bügel, Ko de Ruyter, Oliver Götz, Hans Risselada, and Andrew T. Stephen (2010), "Customer-to-Customer Interactions: Broadening the Scope of Word of Mouth Research," Journal of Service Research, 13 (August), 267-282.

McKee, Daryl, Christina S. Simmers, and Jane Licata (2006), "Customer Self-Efficacy and Response to Service," Journal of Service Research, 8 (February), 207-220.

Meuter, Matthew L., Mary Jo Bitner, Amy L. Ostrom, and Stephen W. Brown (2005), "Choosing among Alternative Service Delivery Modes: An Investigation of Customer Trial of Self-Service Technologies," Journal of Marketing, 69 (April), 61-83.

Mills, Peter K. and James H. Morris (1986), "Clients as "Partial" Employees of Service Organizations: Role Development in Client Participation," Academy of Management Review, 11 (October), 726735.

Mintz, Suzanne G. (1994), "Family Outreach = Image Upgrade," Nursing Homes: Long Term Care Management, 43, 22-24.

Mowen, John C. and Harish Sujan (2005), "Volunteer Behavior: A Hierarchical Model Approach for Investigating Its Trait and Functional Motive Antecedents," Journal of Consumer Psychology, 15, 170-182.

Netemeyer, Richard G., William O. Bearden, and Subhash Sharma (2003), Scaling Procedures. Issues and Applications. Thousand Oaks: Sage Publications.

Payne, Stephanie C. and Sheila S. Webber (2006), "Effects of Service Provider Attitudes and Employment Status on Citizenship Behaviors and Customers' Attitudes and Loyalty Behavior," Journal of Applied Psychology, 91 (March), 365-378.

Peak, Terry (2000), "Families and the Nursing Home Environment: Adaptation in a Group Context," Journal of Gerontological Social Work, 33, 51-66. 
Podsakoff, Philip M., Scott B. MacKenzie, Jeong-Yeon Lee, and Nathan P. Podsakoff (2003), "Common Method Biases in Behavioral Research: A Critical Review of the Literature and Recommended Remedies," Journal of Applied Psychology, 88 (October), 879-903.

Podsakoff, Philip M., Scott B. MacKenzie, Julie B. Paine, and Daniel G. Bachrach (2000), "Organizational Citizenship Behaviors: A Critical Review of the Theoretical and Empirical Literature and Suggestions for Future Research," Journal of Management, 26 (June), 513-563.

Pons, Frank, Mehdi Mourali, and Simon Nyeck (2006), "Consumer Orientation toward Sporting Events," Journal of Service Research, 8 (February), 276-287.

Raudenbush, Stephen W. and Anthony S. Bryk (2002), Hierarchical Linear Models. Applications and Data Analysis Methods. Thousand Oaks, California: Sage Publications.

Rosenbaum, Mark S. and Carolyn A. Massiah (2007), "When Customers Receive Support from Other Customers - Exploring the Influence of Intercustomer Social Support on Customer Voluntary Performance," Journal of Service Research, 9 (February), 257-270.

Ross, Margaret M., Carolyn J. Rosenthal, and Pamela Dawson (1997), "Spousal Caregiving in the Institutional Setting: Visiting," Journal of Clinical Nursing, 6 (November), 473-483.

Sharma, Neeru and Paul G. Patterson (1999), "The Impact of Communication Effectiveness and Service Quality on Relationship Commitment in Consumer, Professional Services," Journal of Services Marketing, 13, 151-170.

Singh, Jagdip (2000), "Performance Productivity and Quality of Frontline Employees in Service Organizations," Journal of Marketing, 64 (April), 15-34.

Strauss, Anselm L. and Juliet M. Corbin (1998), Basics of Qualitative Research: Techniques and Procedures for Developing Grounded Theory. Thousand Oaks, CA: Sage Publications.

Taormina, Robert J. (2004), "Convergent Validation of Two Measures of Organizational Socialization," International Journal of Human Resource Management, 15 (February), 76-94. 
van Doorn, Jenny, Katherine N. Lemon, Vikas Mittal, Stephan Nass, Doreén Pick, Peter Pirner, and Peter C. Verhoef (2010), "Customer Engagement Behavior: Theoretical Foundations and Research Directions," Journal of Service Research, 13 (August), 253-266.

Verhoef, Peter C., Werner J. Reinartz, and Manfred Krafft (2010), "Customer Engagement as a New Perspective in Customer Management," Journal of Service Research, 13 (August), 247-252.

Yi, Youjae and Teashik Gong (2008), "If Employees "Go the Extra Mile," Do Customers Reciprocate with Similar Behavior?," Psychology \& Marketing, 25 (October), 961-986.

Yin, Robert K. (2009), Case Study Research: Design and Methods. California: Sage Publications.

Zeithaml, Valarie A., Mary Jo Bitner, and Dwayne D. Gremler (2009), Services Marketing. Integrating Customer Focus across the Firm. Boston: McGraw Hill. 


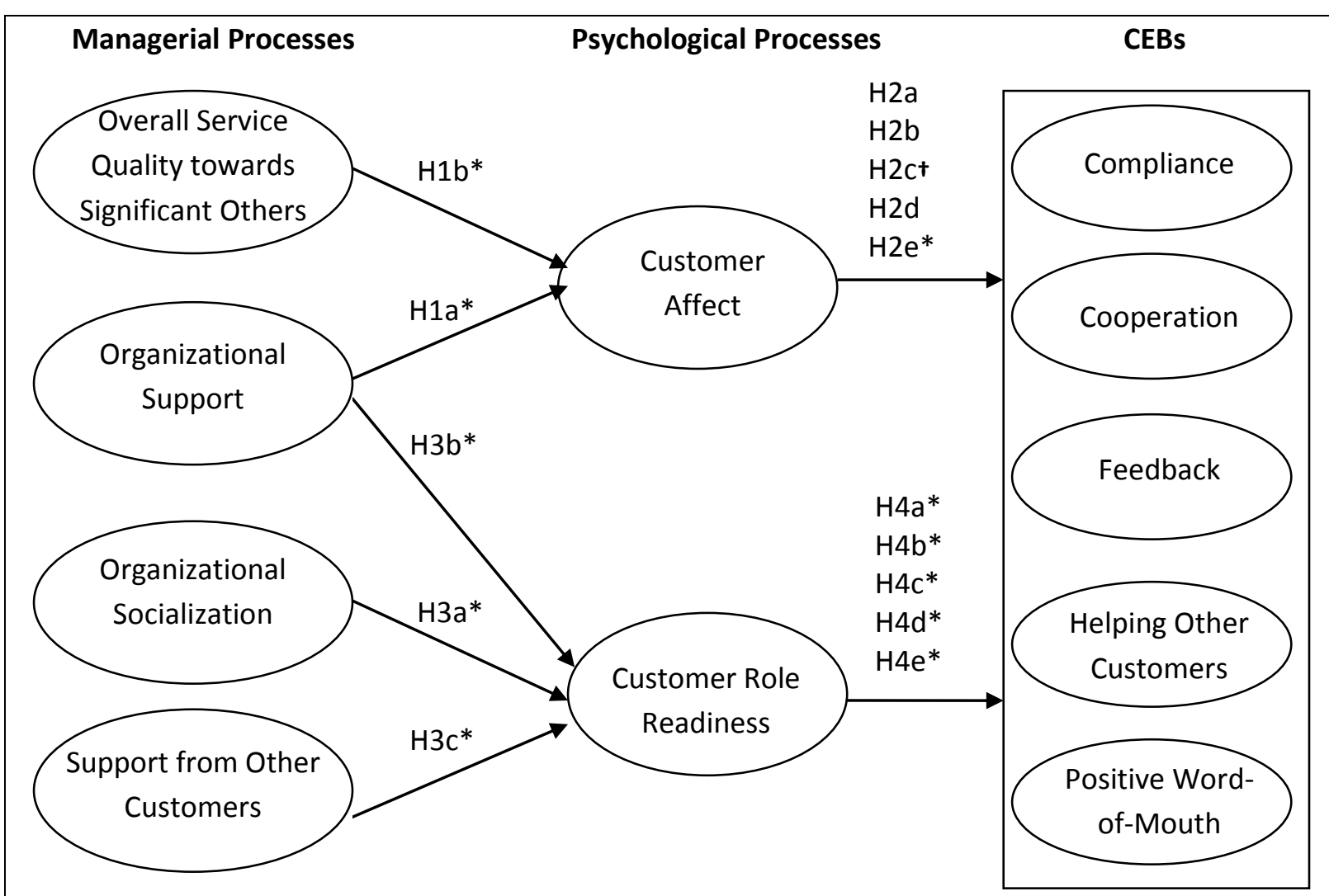

Note. CEBs $=$ customer engagement behaviors; ${ }^{*}=$ supported hypothesis; ${ }^{\dagger}=$ opposite effect.

Figure 1. Theoretical Model on CEBs Embedded in a Broader Network of Customers and/or Stakeholders. 
Table 1. Organizational Socialization and Support throughout the Admission Process.

\begin{tabular}{|c|c|c|c|c|c|c|c|}
\hline \multirow[b]{2}{*}{ STAGE } & \multicolumn{3}{|c|}{ SOCIALIZATION } & \multicolumn{4}{|c|}{ SUPPORT } \\
\hline & Written information and guidelines & $\begin{array}{c}\text { Oral information and } \\
\text { guidelines }\end{array}$ & Visual information & $\begin{array}{c}\text { FEs trying to } \\
\text { understand needs }\end{array}$ & Emotional support from FEs & $\begin{array}{l}\text { Practical help } \\
\text { from FEs }\end{array}$ & Support from OCs \\
\hline 1 & $\begin{array}{l}\text { Website and brochures with } \\
\text { information about organizational } \\
\text { values, facilities, services, and } \\
\text { activities within NH and contact } \\
\text { information of SA } \\
\text { - Information package for potential } \\
\text { customers, including link to website, } \\
\text { brochure, "rules of procedure" and } \\
\text { price list (either handed or mailed } \\
\text { by SA) }\end{array}$ & $\begin{array}{l}\text { - In-take meeting with SA } \\
\text { to run through the } \\
\text { provided written } \\
\text { information and give } \\
\text { additional information } \\
\text { about what to expect }\end{array}$ & & $\begin{array}{l}\text { - SA gathering } \\
\text { information from } \\
\text { FMs about the } \\
\text { potential new } \\
\text { resident during } \\
\text { in-take meeting }\end{array}$ & $\begin{array}{l}\text { - SA listening and open to } \\
\text { FMs' questions and } \\
\text { concerns }\end{array}$ & & \\
\hline II & & $\begin{array}{l}\text { - SA and HN respond to } \\
\text { questions and give more } \\
\text { information about the } \\
\text { way of working within } \\
\text { the NH }\end{array}$ & $\begin{array}{l}\text { - Guided tour in NH } \\
\text { and the } \\
\text { department in } \\
\text { which a room is } \\
\text { available by SA } \\
\text { and/or HN }\end{array}$ & $\begin{array}{l}\text { - IDEM STAGE I } \\
\text { - SA and HN } \\
\text { listening to FMs' } \\
\text { preferences and } \\
\text { needs }\end{array}$ & $\begin{array}{l}\text { - IDEM STAGE I } \\
\text { - SA and HN showing } \\
\text { empathy for difficult } \\
\text { situation }\end{array}$ & & \\
\hline III & $\begin{array}{l}\text { - SA runs through rules of procedures } \\
\text { within NH and asks FMs to read and } \\
\text { sign these forms }\end{array}$ & $\begin{array}{l}\text { - SA and/or HN provide } \\
\text { information about } \\
\text { expectations towards } \\
\text { the FMs during } \\
\text { admission }\end{array}$ & & - IDEM STAGE II & - IDEM STAGE II & $\begin{array}{l}\text { - SA and HN } \\
\text { giving practical } \\
\text { guidelines } \\
\text { about } \\
\text { admission }\end{array}$ & \\
\hline IV & $\begin{array}{l}\text { - Posters with behavioral guidelines } \\
\text { within the NH (e.g. "Please close the } \\
\text { door when you leave the NH } \\
\text { department") }\end{array}$ & $\begin{array}{l}\text { - SA and/or HN and FEs } \\
\text { within the department } \\
\text { provide information } \\
\text { about the way of } \\
\text { working within the NH }\end{array}$ & & - IDEM STAGE II & $\begin{array}{l}\text { - IDEM STAGE II } \\
\text { - Briefing to inform all FEs } \\
\text { in department about new } \\
\text { resident to avoid asking } \\
\text { the same questions to } \\
\text { FMs } \\
\text { - FEs in department } \\
\text { showing empathy }\end{array}$ & $\begin{array}{l}\text { FEs in } \\
\text { department } \\
\text { offering help to } \\
\text { FMs }\end{array}$ & \\
\hline $\mathrm{V}$ & $\begin{array}{l}\text { - Newsletter for FMs } \\
\text { - Billboards within the NH } \\
\text { - Posters with behavioral guidelines }\end{array}$ & & & - IDEM STAGE II & - IDEM STAGE IV & - IDEM STAGE IV & $\begin{array}{l}\text { - Practical help from } \\
\text { OCs } \\
\text { - Emotional support } \\
\text { from OCs during } \\
\text { discussion groups }\end{array}$ \\
\hline
\end{tabular}

Note. FEs = frontline employees; OCs = other customers; $\mathrm{NH}=$ nursing home; $\mathrm{SA}=$ social assistant; $\mathrm{HN}$ = head nurse; FMs = family members:

STAGE I = pre-registration stage; STAGE II = profile matching stage; STAGE III = assignment stage; STAGE IV = admission stage; STAGE V = settling in stage. 
Table 2. Constructs and CFA Results for CEB Scales.

\begin{tabular}{|c|c|c|}
\hline \multirow[t]{2}{*}{ Constructs and Items (FM/FE questionnaire) } & \multicolumn{2}{|c|}{ Factor Loading } \\
\hline & FM Sample & FE Sample \\
\hline \multicolumn{3}{|l|}{ Compliance } \\
\hline I/FMs perform all required tasks & 0.86 & 0.48 \\
\hline $\begin{array}{l}\text { I/FMs help the organization with those things that are } \\
\text { required }\end{array}$ & 0.81 & 0.62 \\
\hline I/FMs adequately complete all expected behaviors & 0.65 & 0.73 \\
\hline I/FMs fulfill my/their responsibilities to the organization & 0.83 & 0.77 \\
\hline \multicolumn{3}{|l|}{ Cooperation } \\
\hline I/FMs do things to make the personnel's job easier & 0.70 & 0.90 \\
\hline $\begin{array}{l}\text { I/FMs try to help the service provider to deliver the best } \\
\text { possible treatment }\end{array}$ & 0.82 & 0.53 \\
\hline \multicolumn{3}{|l|}{ Feedback } \\
\hline $\begin{array}{l}\text { I/FMs let this NH know of ways to better serve my/their } \\
\text { needs }\end{array}$ & 0.75 & 0.82 \\
\hline I/FMs inform NH personnel if I/they experience a problem & 0.81 & 0.53 \\
\hline $\begin{array}{l}\text { I/FMs let the NH personnel know when they give good } \\
\text { service }\end{array}$ & 0.74 & 0.49 \\
\hline \multicolumn{3}{|l|}{ Helping other customers } \\
\hline $\begin{array}{l}\text { I/FMs assist other customers in finding their way within the } \\
\mathrm{NH}\end{array}$ & 0.83 & 0.84 \\
\hline I/FMs help other customers if necessary & 0.70 & 0.80 \\
\hline $\begin{array}{l}\text { I/FMs explain to other customer which services are } \\
\text { provided by the organization }\end{array}$ & 0.78 & 0.75 \\
\hline \multicolumn{3}{|l|}{ Positive word-of-mouth } \\
\hline $\begin{array}{l}\text { I/FMs recommend this } \mathrm{NH} \text { to people interested in nursing } \\
\text { homes }\end{array}$ & 0.89 & 0.95 \\
\hline I/FMs recommend this $\mathrm{NH}$ to family and friends & 0.88 & 0.97 \\
\hline I/FMs say positive things about this NH to others & 0.86 & 0.62 \\
\hline
\end{tabular}

Note. $\mathrm{CEB}=$ customer engagement behavior; $\mathrm{FM}$ = family member; $\mathrm{FE}=$ frontline employee; $\mathrm{NH}=$ nursing home. 
Table 3. Internal Consistency, Reliability, AVE, and Correlation Matrix for CEB Scales.

\begin{tabular}{|c|c|c|c|c|c|c|c|c|c|}
\hline \multicolumn{10}{|l|}{ Family Member Sample } \\
\hline Constructs & $M$ & $S D$ & $C R$ & $\begin{array}{l}\text { Cronbach's } \\
\text { Alpha }\end{array}$ & 1 & 2 & 3 & 4 & 5 \\
\hline 1. Compliance & 4.22 & .57 & .87 & .85 & .79 & & & & \\
\hline 2. Cooperation & 3.14 & .79 & .74 & .72 & $.37^{*}$ & .76 & & & \\
\hline 3. Feedback & 4.02 & .62 & .81 & .81 & $.61^{*}$ & $.57^{*}$ & .77 & & \\
\hline 4. Helping other customers & 3.74 & .66 & .82 & .81 & $.59^{*}$ & $.56^{*}$ & $.71^{*}$ & .77 & \\
\hline 5. Positive WOM & 4.15 & .64 & .91 & .91 & $.58^{*}$ & $.32 *$ & $.54^{*}$ & $.60 *$ & .88 \\
\hline \multicolumn{10}{|l|}{ Frontline Employee Sample } \\
\hline Constructs & $M$ & $S D$ & $C R$ & $\begin{array}{l}\text { Cronbach's } \\
\text { Alpha }\end{array}$ & 1 & 2 & 3 & 4 & 5 \\
\hline 1. Compliance & 3.53 & .46 & .75 & .74 & .66 & & & & \\
\hline 2. Cooperation & 3.27 & .66 & .70 & .54 & .41 & .74 & & & \\
\hline 3. Feedback & 3.93 & .47 & .65 & .68 & $.55^{*}$ & $.50 *$ & .63 & & \\
\hline 4. Helping other customers & 3.66 & .62 & .84 & .83 & $.36^{*}$ & $.61^{*}$ & $.63^{*}$ & .80 & \\
\hline 5. Positive WOM & 3.98 & .56 & .89 & .85 & $.38^{*}$ & .11 & $.60 *$ & .37 & .86 \\
\hline
\end{tabular}

Note. $\mathrm{CEB}=$ customer engagement behavior; $M=$ mean construct score (unweighted); $S D=$ standard deviation; $C R$ = composite reliability; the diagonal (in italics) shows the square root of the AVE for each construct; the off-diagonal numbers represent the correlations among constructs; ${ }^{*} p<.05$. 
Table 4. Constructs and CFA Results for the Main Study.

Constructs and Items Factor Loading

Organizational socialization

The NH personnel keeps me well informed

0.73

The NH personnel explained the treatment options in a meaningful way

0.76

The NH personnel explained me the pros and cons of the proposed treatment

0.80

The organization has provided excellent guidelines about my role in the $\mathrm{NH}$

0.85

The NH instructions and guidelines have enabled me to fulfill my role within the $\mathrm{NH}$

0.82

Instructions given by NH personnel have been valuable in helping me to better fulfill

0.77

my role

Organizational support

The NH personnel is willing to help me when I have a special request

0.71

The NH personnel is very concerned about the welfare of their customers

0.75

The NH personnel is willing to listen to my questions and problems

0.88

The NH personnel can be relied on when I have questions or problems

0.89

Support from other customers

Other residents and family members can be relied on when I have questions

0.71

Other residents and family members are willing to listen to my problems

0.75

Other residents and family members are very helpful

0.88

Overall service quality towards significant others (Dagger, Sweeney, and Johnson 2007)

The quality of the service provided at the $\mathrm{NH}$ is impressive

0.90

The service provided by the $\mathrm{NH}$ is of a high quality

0.81

I believe that the $\mathrm{NH}$ offers service that is superior in every way

0.92

Customer role readiness (McKee, Simmers, and Licata 2006)

I know how to deal with the employees in the $\mathrm{NH}$

0.73

I know how to use the services of the $\mathrm{NH}$

0.81

I feel like I fit in with the other customers of the NH

0.69

Customer affect (Chan, Yim, and Lam 2010)

I am satisfied with the services provided in the $\mathrm{NH}$

0.92

The service of this $\mathrm{NH}$ meets my expectations

0.89

This $\mathrm{NH}$ is a good $\mathrm{NH}$

0.91

$\begin{array}{ll}\text { The service of this } \mathrm{NH} \text { meets my family member's expectations } & 0.92 \\ \text { Overall, I am satisfied with the service provided by this NH } & 0.90\end{array}$

Compliance

See items in Table 2 - factor loadings respectively $0.68,0.92,0.88,0.86$

Cooperation

See items in Table 2 - factor loadings respectively 0.87 and 0.76

Feedback

I let this NH know of ways to better serve my needs $\quad 0.88$

$\begin{array}{ll}\text { I inform NH personnel if I experience a problem } & 0.92\end{array}$

I make constructive suggestions to this organization to improve its service $\quad 0.87$

$\begin{array}{ll}\text { I give useful ideas to someone in the } \mathrm{NH} & 0.63\end{array}$

Helping other customers

See items in Table 2 - factor loadings respectively 0.69, 0.92, and 0.94

Positive WOM

See items in Table 2 - factor loadings respectively $0.95,0.96$, and 0.87

Note. All items used a 7-point scale, ranging from strongly disagree (1) to strongly agree (7); $\mathrm{NH}=$ nursing home; $\chi^{2}=1358.98, d f=685, \chi^{2} / d f=1.53$, comparative fit index $(C F I)=0.98$, Tucker-Lewis Index $(T L I)=0.98$, and root mean square error of approximation (RMSEA) $=0.06$. 
Table 5. Internal Consistency, Reliability, AVE, and Correlation Matrix for the Main Study.

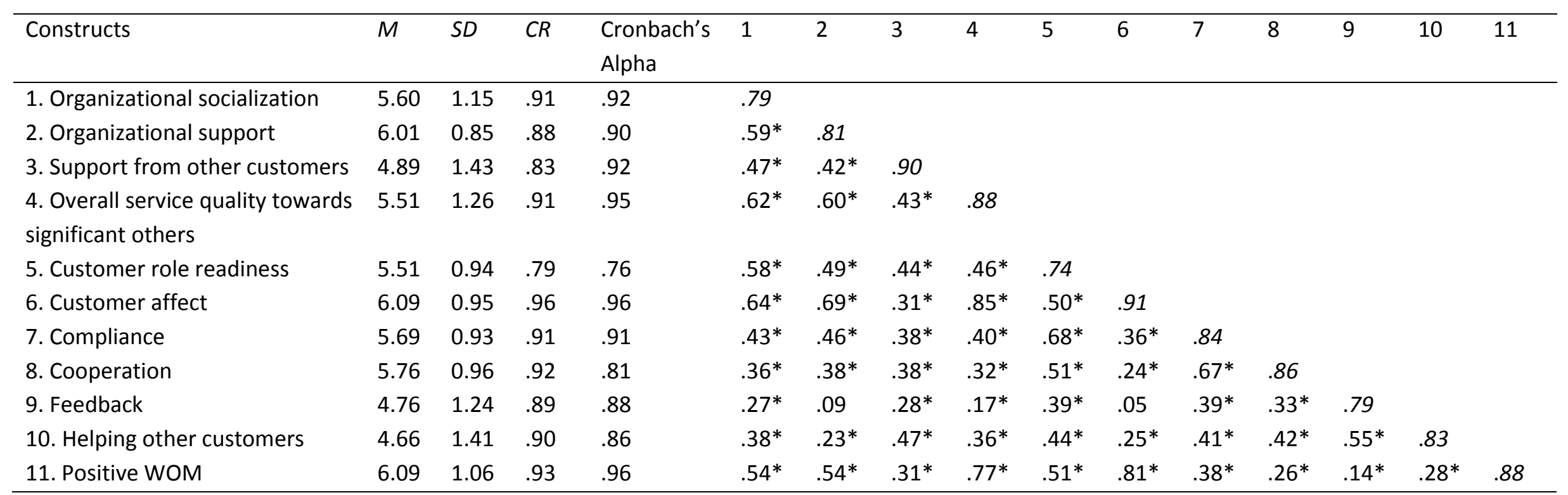

Note. $M=$ mean construct score (unweighted); $S D=$ standard deviation; $C R=$ composite reliability; the diagonal (in italics) shows the square root of the AVE for each construct; the off-diagonal numbers represent the correlations among constructs; * $p<.05$. 
Table 6. Hierarchical Regression Results for CEBs Embedded in a Broader Network of Customers and/or Stakeholders.

\begin{tabular}{|c|c|c|c|c|c|c|c|c|c|c|}
\hline \multirow{2}{*}{$\begin{array}{l}\text { Variable } \\
\text { Step } 1\end{array}$} & \multicolumn{2}{|c|}{ Compliance } & \multicolumn{2}{|c|}{ Cooperation } & \multicolumn{2}{|c|}{ Feedback } & \multicolumn{2}{|c|}{$\begin{array}{l}\text { Helping Other } \\
\text { Customers }\end{array}$} & \multicolumn{2}{|c|}{ Positive WOM } \\
\hline & $B$ & $t$ & $B$ & $t$ & $B$ & $t$ & $B$ & $t$ & $B$ & $t$ \\
\hline Constant & 5.51 & $40.61 * * *$ & 5.54 & $39.09 * * *$ & 4.65 & $26.98 * * *$ & 4.24 & $20.89 * * *$ & 6.12 & $40.19 * * *$ \\
\hline Gender (RC=women) & .02 & .22 & .00 & .04 & -.05 & -.40 & -.01 & -.09 & -.14 & -1.27 \\
\hline Retirement $(\mathrm{RC}=$ not retired $)$ & .20 & $2.06 * *$ & .11 & 1.08 & .12 & .99 & .34 & $2.32 * *$ & .28 & $2.49 * *$ \\
\hline Kinship ( $\mathrm{RC}=$ other than child) & .05 & .48 & .22 & $2.01 * *$ & .08 & .63 & .31 & $2.00 * *$ & -.01 & -.12 \\
\hline \multirow[t]{2}{*}{ LOR with $\mathrm{NH}(\mathrm{RC}=\leq 2$ years) } & -.01 & -.11 & -.01 & -.05 & .12 & 1.00 & .05 & .32 & -.16 & -1.50 \\
\hline & \multicolumn{2}{|c|}{$R^{2}=.01$} & \multicolumn{2}{|c|}{$R^{2}=.01$} & \multicolumn{2}{|c|}{$R^{2}=.01$} & \multicolumn{2}{|c|}{$R^{2}=.02$} & \multicolumn{2}{|c|}{$R^{2}=.03$} \\
\hline Step 2 & $B$ & $t$ & $B$ & $t$ & $B$ & $t$ & $B$ & $t$ & $B$ & $t$ \\
\hline Constant & 4.29 & $18.44 * * *$ & 4.54 & $18.27^{* * *}$ & 2.69 & $9.40 * * *$ & 2.52 & $7.18^{* * *}$ & 4.95 & $18.74 * * *$ \\
\hline Gender ( $\mathrm{RC}=$ women) & .01 & .14 & .00 & -.01 & -.06 & -.54 & -.02 & -.14 & -.15 & -1.38 \\
\hline Retirement $(\mathrm{RC}=$ not retired $)$ & .17 & $1.81^{*}$ & .08 & .84 & .07 & .60 & .30 & $2.13^{* *}$ & .25 & $2.39 * *$ \\
\hline Kinship ( $\mathrm{RC}=$ other than child) & .02 & .25 & .20 & $1.88^{*}$ & .07 & .55 & .27 & $1.81^{*}$ & -.05 & -.42 \\
\hline LOR with $\mathrm{NH}(\mathrm{RC}=\leq 2$ years) & .00 & .04 & .00 & .05 & .16 & 1.43 & .05 & .39 & -.16 & -1.56 \\
\hline NHR related motive & .12 & $3.04 * * *$ & .09 & $2.34 * *$ & .27 & $5.73 * * *$ & .08 & 1.33 & -.01 & -.25 \\
\hline \multirow[t]{2}{*}{$\mathrm{NH}$ related motive } & .14 & $3.26 * * *$ & .11 & $2.52 * *$ & .14 & $2.75^{* *}$ & .27 & $4.39 * * *$ & .24 & $5.19 * * *$ \\
\hline & \multicolumn{2}{|c|}{$R^{2}=.11$} & \multicolumn{2}{|c|}{$R^{2}=.07$} & \multicolumn{2}{|c|}{$R^{2}=.17$} & \multicolumn{2}{|c|}{$R^{2}=.11$} & \multicolumn{2}{|c|}{$R^{2}=.11$} \\
\hline
\end{tabular}

Note. $\mathrm{RC}=$ reference category; LOR = length of relationship; $\mathrm{NH}=$ nursing home; $\mathrm{NHR}=$ nursing home resident; $*<.10 ; * *<.05 ; * * *<.01$. 
Table 7. Structural Model Results for the Main Study.

\begin{tabular}{|c|c|c|c|c|c|c|c|}
\hline Structural Paths & Compliance & Cooperation & Feedback & $\begin{array}{l}\text { Helping } \\
\text { Other } \\
\text { Customers }\end{array}$ & $\begin{array}{l}\text { Positive } \\
\text { WOM }\end{array}$ & $\begin{array}{l}\text { Supported } \\
\text { Hypotheses }\end{array}$ & $\begin{array}{l}\text { Not } \\
\text { Supported } \\
\text { Hypotheses }\end{array}$ \\
\hline OSU - customer affect & $.53^{* *}$ & $.53^{* *}$ & $.53^{* *}$ & $.53^{* *}$ & $.53^{* *}$ & $\mathrm{H} 1 \mathrm{a}$ & \\
\hline OSQ - customer affect & $.32 * *$ & $.32 *$ & $.32 * *$ & $.32 * *$ & $.32 * *$ & $\mathrm{H} 1 \mathrm{~b}$ & \\
\hline Customer affect - CEB & .04 & -.02 & $-.28 * *$ & .04 & $.69 * *$ & $\mathrm{H} 2 \mathrm{e}$ & $\mathrm{H} 2 \mathrm{abcd}+$ \\
\hline OSO - role readiness & $.36 * *$ & $.37^{* *}$ & $.41 * *$ & $.40 * *$ & $.39 * *$ & $\mathrm{H} 3 \mathrm{a}$ & \\
\hline OSU - role readiness & $.29 * *$ & $.27^{* *}$ & $.23 * *$ & $.22 * *$ & $.25^{* *}$ & $\mathrm{H} 3 \mathrm{~b}$ & \\
\hline SUOC - role readiness & $.14^{* *}$ & $.14^{* *}$ & $.13^{* *}$ & $.15^{* *}$ & $.12^{* *}$ & $\mathrm{H} 3 \mathrm{c}$ & \\
\hline Role readiness - CEB & $.54 * *$ & $.54 * *$ & $.70 * *$ & $.51 * *$ & $.10 * *$ & H4abcde & \\
\hline$\chi^{2}$ & 868.95 & 785.02 & 858.26 & 847.78 & 902.97 & & \\
\hline$d f$ & 339 & 288 & 339 & 313 & 313 & & \\
\hline RMSEA & .06 & .06 & .06 & .06 & .06 & & \\
\hline CFI & .98 & .98 & .98 & .98 & .98 & & \\
\hline TLI & .98 & .98 & .98 & .98 & .98 & & \\
\hline
\end{tabular}

Note. $\mathrm{OSU}=$ organizational support; $\mathrm{OSQ}=$ overall service quality towards significant others; $\mathrm{OSO}=$ organizational socialization; $S U O C=$ support from other customers; RMSEA = root mean square error of approximation; $\mathrm{CFI}=$ comparative fit index; TLI = Tucker-Lewis Index; ${ }^{*} \mathrm{p}<.05 ;{ }^{*} \mathrm{p}<.01 ;$; opposite effect for $\mathrm{H} 2 \mathrm{c}$. 